University of Rhode Island

DigitalCommons@URI

Open Access Master's Theses

1978

\title{
A Measurement of the Improvement of Attitudes Toward Death in Middle School/Junior High School Students
}

Mary Catherine Holland Canole

University of Rhode Island

Follow this and additional works at: https://digitalcommons.uri.edu/theses

\section{Recommended Citation}

Canole, Mary Catherine Holland, "A Measurement of the Improvement of Attitudes Toward Death in Middle School/Junior High School Students" (1978). Open Access Master's Theses. Paper 1706. https://digitalcommons.uri.edu/theses/1706

This Thesis is brought to you for free and open access by DigitalCommons@URI. It has been accepted for inclusion in Open Access Master's Theses by an authorized administrator of DigitalCommons@URI. For more information, please contact digitalcommons-group@uri.edu. 
A MLASUREIENT OF THE IYPROVEHEIT OF ATTILUDES

TOWARD DEATH IN INIDDLE SCHOOL/JUINIOR HIGH SCHOOL STUDENTS

BY

IIARY CATHERIINE HOLLAND CAITOLE

\author{
THESIS PROJECI \\ PRESENTED IN PARTIAL FULFILLEENT OF THE \\ REGUIRHEHTS FOR THE DEGRES OF \\ MASTLRS OF SCIENCE \\ IN \\ HOHE ECONOHICS EDUCATION
}

UNIVERSITY OF RHOLE ISLAND

1978 


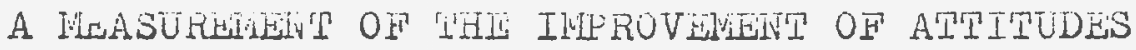
TOWARD DEATH IN MIDDLL SCHOOL/JUNIOR HIGH SCHOOL STUDENTS

Children today have a limited knowledge and experience with death in our culture. This lack of experience has resulted in the tremendous fear of the unknown - death. Death education has been an attempt to reduce a child's anxiety toward death. Since it was uncertain whether death education was effective with young children this study was developed to test whether students being exposed to a death education program would have a better attitude toward ceath than students who had not had any death education. Death education hopefully irnproves one's attitude toward death.

One hundred and forty-six randomly selected students were surveyed from six of the riddle/junior high schools in Rhode Island that included death education in their curriculum. Seventy-three of the students were exposed to the treatment, death oducation (experinental group) and the other seventy-three had no treatment (control group). The Hardt Death Attitude Scale was the instrument used to deterine the attitude toward death of students in each grour. 
Two self-developed instruments were also used by the researcher. A Teacher's Survey and a Student's Survey were used to determine first the content of the death education program in each school as well as the experience of the teacher; and second, the previous experiences students have had with death.

The design of the study was a posttest only control group. Students were posttested with the Hardt test and the difference in means between the control group and the experimental group was computed. A T-Test for dependent samples was employed to determine whether the difference was statistically significant. The T-Test proved that there was a significant difference in mean scores of the two groups and the null hypothesis - There is no significant difference in attitudes toward death between students who have been exposed to death education in school and students who have not been exposed to death education - was rejected.

Results of this study indicated that students who had been exposed to death education had a more positive attitude toward death. Thus, death education is effective. 
ACKNOWLEDGEMEITS

The author wishes to extend her most heartfelt thanks to Dr. Patricia Smith Kelly, Chairman of the Department of Home Economics Education, for her constant encouragement and direction in seeing this research project through from beginning to end. For the author it was an unforgettable experience working with such an enthusiastic professional. Appreciation is also extended to the other members of her graduate committee: Dr. Nancy Blackman, Dr. Marjorie Bumpus, Dr. Louise MacKenzie and Dr. Donald Spence who gave up their time to offer help and suggestions. Finally, a sincere thank you is extended to the author's parents for their constant reassurance and help, and to John, the author's husband, for his assistance, patience and understanding throughout this entire project. 


\section{TABLE OF CONTENTS}

LIST OF TABLES . . . . . . . . . . . . iii

LIST OF FIGURES . . . . . . . . . . . . iv

Chapter

I INTRODUCTION

Orientation to the Froblem ...... 1

Staterient of the Problem ....... 2

Purpose ............... . 2

Hypotheses . . . . . . . . . 3

Definition of lierms .......... 3

As sumptions . . . . . . . . . . . 3

Iimitations of the Report: : : : : 4

II REVIEW OF LITERATURLE

Modern Attitudes Toward Death . . . 7 The Need for Change in Attitudes Toward Death . . . . . . . . . 12 The Effects of Death Education Programs. 17

III WEIHOD

Fopulation and sample ....... . 20 Procedure . . . . . . . . 22

Description of Treatment Group . . . 23

Design of the Study ........ 26

Experimental Design . . . . . . . 27

Statistical Design . . . . . . . 29

Measurement ............ 29 Analysis of Data........... 34

IV FINUTNGS AID DISCUSSION OF REUULTS

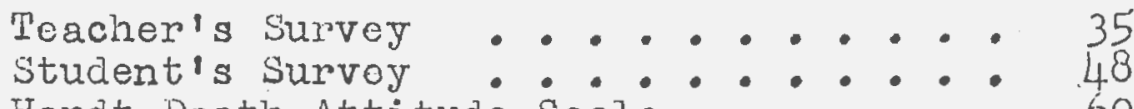
Harat Death Attitude Scale:. . . 60

$\mathrm{V}$ SURHARY AND INPLICALIONS

Sunmary •. . . . . . . . . 65

Implications .............. 67 
APPENDIX
A Pre-Active rhase
$B$ Active Phase
$C$ Hardt Instrument
D Student Test Scores 
LIST OF TABLES

Table

Page

Sample Size

22

2

Death Education Curriculum

36

Death Education Leaming Activities

40

4

Teaching Experience

41

5

Years of Teaching Death Education

42

6

Student Demographic Information

48

Students who Knew Domeone Very Sick

50

8

Students Who Had been Very Sick

50

Students who Had Pets that Died

51

10

Students who had a Friend that Died

52

Students Who had Someone in their House Die

53

Students Who Had Attended a Funeral

54

13

Attendance at Religious Services

55

14

Students Who Had Read With Death

56

15

T-Test

60

16

Mean Values for Individual Schools

61

17

T-Tests for Individual Schools

62 
LIST OF FIGURES

Figure

Page

1

The Experimental Design

27

2

The Ixperimental Design

28 
CHAPTL'R I

INTRODUCTION

Orientation to the Problem

By becoming aware of the subject of aeath and dying we are all being given an unparalleled opportunity - to discover life's true meaning through coming to terms with death's place in the spectrum of human development, and thus to learn to use our gift of life as happily and productively as possible. If you face a problem, whether you are able to solve it or not, you will grow. Death is a problem in our society. We urge you to accept the challenge and opportunity available to you now of dealing with this problem, of facing it squarely. You will grow through the experience (Kubler-Ross, 1975).

Some of our school systems are presently trying to introduce death education into their curriculurns in order to allow children to weigh in their own minds and hearts what death means to them and how they will cope with this complexity throughout the remainder of their lives. Nany schools, however, are finding it very difficult to introduce this topic into their curriculum. In our culture it has become increasingly difficult to accept the inevitability of death because our culture rejects and denies death. Thus, in many locations death is excluded from the schools and our society is leit with a problem. 


\section{Statement of the Problem}

Since death has become a forbidden topic children have a limited knowledge and experience with death. Research indicates that this situation may be responsible for promoting a negative attitude toward death and dying. According to Frankl (Skinner, 1965.4), until we can face death openly and honestly we will not be able to lead a purposeful life. Death education may be what our children need to gain knowledee about death and face death honestly.

During the past ten years studies have been done to determine the effectiveness of teaching the topic of death in school. The goal beinind most death education programs is to give the student an honest and realistic view of death. Hopefully, the prog:am will reduce a student's fear toward deatin.

One researcher, Dr. Dale Hardt, has proven his theory that death education will reduce a student's anxiety toward death by use of his instrument which Ineasures a person's anxiety toward death. Harat, however, demonstrated this proof with college students only. He seerred uncertain as to whether similar results would be obtained if death education was presented to younger students.

In the present study the following question was 
investigated: Will death education programs in the middle/junior high school classrooms ef'fect a student's attitude toward death?

\section{Hypothesis}

Based upon previous research the following null hypothesis is postulated in order to determine the results of teaching death education at the middle/junior high school level.

Hypothesis. There is no significant difference in attitude toward death between students who have been exposed to death education in school and students who have not been exposed to death education.

Other questions that will be examined:

Is there a difference between the death attitude of students attending private and parochial schools and students attending public schools after they have been exposed to death education?

Does the type of death education program have an effect on students' attitudes tow roath in the partjcipating survey schools?

\section{Definition of Terms}

Death - the art or fact of dying; ending of life; the state of being dead.

Death education - teaching about various death topics so others can come to terms with their own mortality. 


\section{Assumptions}

The following assumptions underlie this study:

1. Individual death education prograns are relatively homogeneous in their effect.

2. Hardt's Attitude Scale is an adequate measure of a student's attitude toward death.

3. It is appropriate to randomize for death education experience in terms of students ratiner than in terms of schools since the population of schools teaching death education in Rhode Island is so small.

\section{Limitations}

The following limitations were recognized by the researcher in this study.

1. Since only the state of Rhode Island was sampled there is question whether the findings of this study could represent a national trend.

2. There is no way of measuring what effect an individual teacher had on his/her students' attitude changes. 
Organization of the Report

Chapter I has revealed that there is a real need for this study of the effects of death education. Further review of literature is presented in Chapter II to inform the reader about the writings and research findings that have been reported which have direct implications for this investigation. The areas represented are (1) modern attitudes of death, (2) the need for a change in attitudes, and (3) the effect of death education programs in the schools. The review of literature was undertaken to present a step-by-step approach to a culture's change in attitude toward death and to support the need for this particular study.

In Chapter III the methods and procedure of this study will be introduced. This includes the research design, sample and treatment groups, instrurientation, data collection plan and the plan for analysis of data.

In Chapter IV the analysis and discussion of the data are presented.

The conclusions and recommendations based on the findings of the study are recorded in Chapter $V$. 


\section{CHAPTER II}

REVIEW OF LITERATURE

The review of literature presented in this chapter is divided into three sections, (1) modern attitudes toward death, (2) the need for a change in society's attitudes toward death and (3) the effect of death education programs in the school.

Receiving an idea of modern attitudes toward death is important if one is to realize why a change might be needed. Briefly presented are reasons why death has changed from being an everyday; acceptable occurrence which was talked of openly to a now, newly taboo topic.

The need for change is reviewed to suggest what might happen if a change of attitudes toward death does occur. This review of literature supports the idea of death education.

Finally the section on the effects of death education programs in the school is included to support the assumption that death education will make a difference in changing a student's attitude toward death.

It is the researcher's desire to present through the review of literature a total picture of how death is viewed in American society, why there is a need for a change in attitudes via death education programs, and what the effects of such programs are. 


\section{Llodern Attitudes Toward Death}

Just thirty or forty years ago children were brought up surrounded by the mysteries of birth and death. People were born at home in the company of family and friends. Today's generations, however, have not witnessed the birth of a baby or the death of sorneone close in the family. They have not been part of what life is all about.

Today, people avoid the subject of death, as the Victorians avoided the topic sex. There are reasons why tiis problem has occurred. Grollman (Leviton, 1969, 46-47) believes that since it has become uncommon to witness death in our own lives we corine to avoid and deny death. Technological advances such as monitoring machines and life sustaining systems have resulted in this denial of death. The emphasis today is on healing and prolongation of life. "Transplants and wonder drugs are in; death is out, unpopular and unsung" (Langone, $1972,4)$

Nowadays people live longer lives. Before, since an individual's longevity was shorter, it was more common to witness death in the family home. Today death is meny tines associated with old age and is accepted mostly in that context.

At one time it was customary for family members to die in the home. Now a large percentage of the sick 
and dying are sent off to hospitals and nursing homes away from their family (Kubler - Ross, 1975, Intro.). Another factor which shields today's generations from facing death is the mobility of today's family. The once extended family is now reduced to a nuclear arrangement where it is not uncommon for the separate family groups to live miles apart. When death does occur it seems distant and unreal.

Finally, because of the wonders of modern science death just doesn't seem possible. There always seems to be some sort of cure. Perhaps generations before were more accepting of the inevitability of death (Kubler-Ross, 1975, Intro.).

According to the results of a Psychology Today questionnaire (Schneidman, 1971,44), death has beeome so forbidden a topic in our culture that one third of the respondents could not remember ever discussing death in their homes from an early age. In more than one third of these families, death was talked about with much discomfort and in only 30 percent of the homes was death talked of openly and honestly.

Chicago Psychiatrist Elisabeth Kubler-Ross said:

Americans' avoidance of death is rooted in the breakdown of the 'old fashioned' family unit and the mechanization of medicine. Before medicine became so advanced people died at home - a home more likely than not where several generations of a family lived together. Not only did the dying patient teminate his lifte in a familiar and beloved 
environment, Ross explains, but the patients' children and grandchildren shared in tho process of dying, death, grief and bereavement. No more. Now, older people live in retirenent communities or nursing homes. They die in lonely impersonal hospitals where children under age 12 aren't allowed to vișit.

Another f'actor contributing to society's denial of death is loss of religion and belief of a hereafter. Immortality offered hope and purpose to suffering the dying anticipated a reward in

heaven. That pewer people really believe in life after cleath only multiplies mans' end of life anxiety (Zazzaro, 1973, 39-42).

Because death has becorne a taboo subject in our culture it has become common practice to try and shield our children from confronting deatiz in any form. As a result, today's children have many misconceptions of death.

Attitudes toward death are learned. Iike prejudice or other attitudes, one's basic attitudes toward death are learned srom those closest to him or her. If one's parents and others close to the individual are very fearful toward death and unable to deal with death in any soit of planned or enjoyable manner, then the individual will adopt the same fearful position toward death. There is no easy way to die. There is no easy way to mourn the death of another. Since death is inevitable, families and individuals will have to deal with deatin sooner or later. How well they will be able to handle death depends upon their attitudes toward it: Some attitudes toward death are healthy and make ior less of a crisis for either the individual or the family. Other attitides toward death are less healthy and increase the amount of crisis and make readjustment more painful and tragic laden (Cox, 1976,3). 
Areas outside the home influence children's attitudes toward death. At one time children's literature dealt openly with the concept of death. One child's verse in the New England Primer of 1834 states:

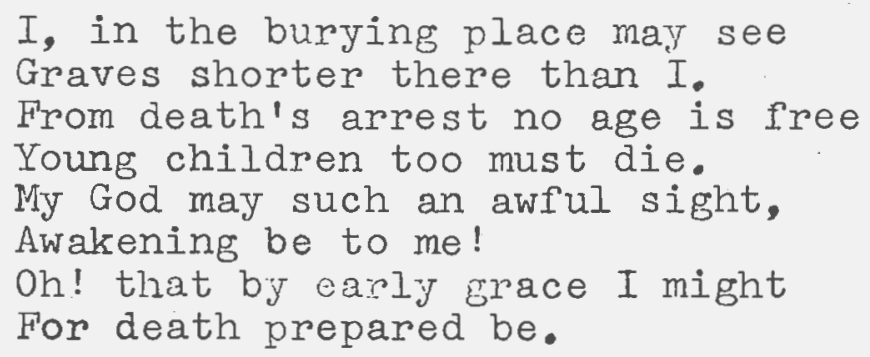

Nowadays, however, children's literature has done a complete turn around and death is looked upon as something to protect children from thinking about.

The happy ending in fairy tales and children's stories. . expresses a need to deny the reality of death. The good grandmother in 'Little Red Riding Hood' steps out of the stomach of the wolf, hale and hearty, representing the complete denial of death. . (Zazzaro, 1973,39).

Children, evidently, are too young to care about death. Adults seem to wait until they have no other alternative than to discuss death. According to Zazzaro (1973,42) neither the practices of the seventeenth, eighteenth, and nineteenth centuries or today's twentieth century practices concerning death are practical. Literature could represent a healthier and more honest approach to death.

Sociologist Robert Fulton, director of the University of Minnesota's Center for Death Education and Research, 
blames the mass media as well as literature for giving children a distorted view of death. "On IV only vgly aliens, bad guys or mythical characters die. Nice American kids don't", Fulton says disapprovingly (Zazzaro, 1973,42).

Children may joke about how "neat" it was for someone to be blown to bits in a novie, yet deep down they are privately troubled about how they will die themselves. It is evident that children are becoming more concerned with death.

Flora Arnstein f'rom San Francisco, California, an English teacher states:

Irring all but the last two years few poems, at most four or five, have been written on war and death. In contrast, during these last two years nore than fifty-two poems have been written on these sibjects. There is an apparent sense of continuous confrontation with the idea of death.

By and large, youngsters are not given to explessing their more profound ideas vocally, yet they seem able through the medium of poetry, not only to explore their thoughts and reelings, but to verbalize these without constraint.

Thus, we acults are siven the opportunity when reading their work to gain some insight into what they are thinging and fooline (Arnstein, 1972,85\%). 
The Need in Change of Attitudes Toward Death

Children need information about death. They need to be able to express their thoughts and concerns about death openly. But how does one know that children are mentally mature enough to accept discussion regarding death, especially their own mortality? It is important that one is aware of the maturation stages of a child concerning the notion of death before that question is answered.

Conceptions of life and death evolve in stages that are roughly related to age. The stages are:

1. From about the age of three to five, children do not understand the meaning of death and do not regard it as discontinuous with, nor in opposition to life.

2. At the second stage, usually ages six to nine, children begin to think of death as discontinuous with life but as reversible and not applicable to everyone (Hollis, 1975,27).

Most kids have very literal minds; they love details and facts. When they are free to ask questions, they want to know about dying in a way that relates to them. Did it hurt?. Where is so and So right now? Did they mail him away in that box? Will he come back again like when Uncle Glenn came back from the war. The key question, if a parent is lucky (Lucky, because only a "free" child can ask so terrible query), is Are you going to die/ am I going to die?

It is vital to answer as honestly as we can, or to simply say: 'I don't know...' ' when a child asks, 'What does it mean, dead?' (Mackey, 1978,156).

3. Then at the last stage, beginning at about the age of ten or eleven, 
children begin to view death as

irreversible and in medical/

biological terms (Hollis, 1975, 27).

Adolescence, then, is the time when death is recognized and accepted. Treenagers are aware that they and their loved ones will someday die. However, the notion of death is something that is not looked on upon as possibly happening in the present. Death to the adolescent is a future event and not to be worried about in the present. Thus, it is quite easy, for the twelve yoor old adolescent to look at the many different perspectives of death (religious, biological, personal) and to accept them (Hollis, 1975).

Since it is possible for a child to accept information about death in each stage of his maturation process it is important that discussions of death be brought out into the open; if not through the family unit then through the schools.

Elisabeth Kubler-Ross (Looking At: Death and Dying, 1975,15) seems to capture all the important reasons why death education should be part of a child's schooling today. She was asked the question - Do you feel that death and dying should be taught in the classroom? Her reply:

The younger the better!. . If you can reach fourth graders and talk with them about death, without lecturing them, you can do a lot of preventive psychiatry. If people at a younger age would accept death as a normal part of life, they 
would have a very different appreciation of life. If children are to experience death as a natural occurrence, the first thing we have to do nationwide is take down those stupid signs in hospitals that say 'no children allowed'. Ir you avoid the issues of illness, old age, and death with children, they are naturally not prepared. Wiy big drear is that you take most people home to die. we ship old people to nursing homes: prandmas come home for Christmas, and then we ship them off again. This gives the child no experience with old ase. We sinip patients to hospitals and virtually exclude children irom visiting sick people. They naturally must think that someting horrible is going on behind those walls. Why can't we share our erief, our fears, our anger, our anxieties? We need to take the rinstery out of aeath along with the pretense and the lies.

Young people need more than silence from adults about death. Without information young people's anxiety and concern increases. I'hey cannot develop an unäerstanoing toward death unless adults understand their need and open up to them. If adults wait until the death of a family member or a good friend to discuss the issue it may be too late. The goal of cieath education in the schools is to give young people the information they need to help understand this phenomenon. Teachers of death education hope to fill the void in young people's experience in order for them to retain a proper perspective on what lif'e is all about.

But winat is death education? To teach about death is to teach about many things. Death involves the subject areas of science and medicine, social studies 
and sociology, psychology, history, art, literature, music, insurance and law. Death education seeks to: (1) oven up tine lines oi communication about death, (2) stop using euphemisns and use "direct language" concerning death, (3) teach that feelings exist and there is strength in expressing feelings such as fear, relief, guilt and protest honestly, and $(4)$ consider how young people might handle grief. Rolenlaying is used to demonstrate response to the death of a relative or their own death (Berg and Daugherty, 1973,46). According to Daniel Leviton, director of a death education program:

Death Education should have an ultimate goal - increased human hapriness. Our goal is to help people understand their own feeling and attitudes toward death and dying. Then death will be less reantul and living more onjoyable. The role of school death education, which is basically non-moral is complementary to that received in the home and church. Its role is to disseminate the results of scientific information and philosophical thought, which may very well be nonexistent for parents, as well as for a large number of theologians, chysicians and others (Green and Irish, i971).

Elisabeth Kubler Ross feels that childien can come to grips with death if they have one grown up who can talk about it without turning it into a nightinare. The rationale behind aeath education programs is: 
1. Piental health of chilaren as well as adults depends not upon the denial of tragedy, but upon the frank acknowledgement of it. A well-designed and carefully considered death education program should be made avrilable to all children.

2. As most fears are learned reactions, grining knowled about various aspects of death can serve to reduce rears and misunderstandings.

3. It is likely that a child's ability to cope with a particular death may bo facilitated if prior discussions of death in general have talsen place. Such discussions should introduce the subject gently and in terms the child can understand.

4. Incorporation of death education, into the school curriculum should not take the form of isolated instruction. Rather much of the content should be integrated with relevant aspects of the existing. curricula (Hills, Reisler, 1976).

Reasons that the author Shibles gives for the study of death are (1) By inquiring about death one can help cope and overcome his/her fear of it. Merely discussing death will reduce fear, shock, and anxiety. for the student who will someday face the death of someone close to him/her. (2) By facing death in discussions, one is very apt to lead a mope purposeful life and to make it the best he can for himself and others. (3) Inquiry about death helps one make the concept of death clearer. (4) One tends to be more honest and realistic when he/she considers death. (5) By studying death one really studies life and love (Shibles, i974,iv). 
The Iffect of Death Education Programs

Not long ago education authorities, writers in the press, parents, teachers, and the 'man in the street' were shocked to hear of a certain school which had been holding 'death lessons'. The outcry was interesting because it revealed a deep emotional fear of death (iritchell, 19ó 7,1).

Nurses at Texas School of Nursing took part in a death education program consisting of theory and clinical application to the thoory.

In responding to a questionnaire administered between two and twentyfour months after the unit, $90 \%$ of the responding students said they thought the learning experience had improved their nursing care of the dying. They felt better able to cope with their own fear of death, felt more acceptance for the dying, and knew speciric ways for interacting with, and caring for the dying (Wise, 1974, 42-44).

Christine Fontenot, an English teacher at Loreauville High School, Loreauville, Louisiana presented the topic of death in her eleventh and twelfth grade classes after. their study of the authors Steinbeck, Harte, and Donne. (all works dealing with death in some way). After surveying her students at the end of the unit it was found that 94 out of 96 students agreed that the unit had been "a worthwhile, mearingful, and helpful experience", and 93 agreed that a study of death "makes life more precious and meaningful" (Fontenot, 1974,62-63).

The above studies seem to indicate that death 
education is effective when measured by subjective means. The educator, Dale Hardt, however, was not content with measuring death education effectiveness in this manner. Harat relt that past ex eriences with death education classes were not measured accurately. Mieasurements were not reliable or valid. It was the lack of valid. and reliable measures which prompted Hardt to develop an instrument to measure attitudes toward the concept of death (Hardt, 1976,269).

The attitude scale developed by Hardt was a Thurston Equal Appearing Interval attitude scale. Using the split half method of reliability with the Spearman Brown "Prophecy Formula" serving as an adjustment formula, a reliability coefficient of .87 was produced for the scale. The scale was also readable by 5 th grade level and above as judged by criteria set forth by Flesch (1949) and by Dale and Chall (1948). A copy of this instrument is provided in Appendix C.

The results of the scale development provide a valid, reliable means to determine the mean, range and stondard deviation of the attitudes of potential learners and change that has occurred after the educational experience.

After developing his instrument Hardt set up a study using his scale to measure change in death attitudes of college students who were exposed to a death intervention program. Classroon presentations, discussions and froup 
activities were the make up of the program. The results were that each group increased or improved in death attitude score from pre-test to post-test. The mean death attitude score for all subjects on the Death Attitude Scale prior to class was 3.074. Post-test results show a mean attitude score of 3.318 or a .244 increase. This difference was demonstrated statistically significant by a directional "t" test at the .05 level. (Harcit, 1976, 269-270).

Thus, to the researcher it would seem that if death education had such a positive impact on college level and high school level students it would also bring the same results to middle/junior high school stidents. 


\section{CHAPTER III}

IMETHOD

A study was designed to determine the effects of death education on the attitudes of middle/junior high school students toward death. The researcher hoped to duplicate as closely as possible the study performed by Hardt discussed in the Review of Literature.

Permission was granted by Hardt to use his instrument in completing this study (Appendix C). This study would follow the recommendation f'ound in Hardt's article: "A Measurement of the Improvement of Attitude Toward Death" (Hardt, 1976,270) which suggested that the study be duplicated on less than college level students to see if results were still valid.

Along with Hardt's Death Attitude Scale an additional survey instrument was created by the researcher to determine a student's past experiences with death. Findings from this instrument were to be of a purely descriptive nature. No test for validity was determined for this survey.

Population and Sample

The sample for this study consisted of 146 students from six middle/junior high schools (grades 5,6,7,8, and 9) in Rhode Island that had death education as part of their curriculum. Students from these six schools fell into 
two categories. Seventy-three students who had had death education were randomly selected from all six schools for the experimental group while seventy-three students who had not had death education were matched according to grade level and school to the students in the experimental group. Ihis group of students who had not had death education would serve as the control.

In order to obtain the above sample it was first necessary to survey the entire population of public, private and parochial middle/junior high schools in Rhode Island to determine what schools actually offered death education. The total population of Khode Island middle/junior high schools was 115. The number of schools that taught death education and that were willing to take part in the survey was six.

The researcher had some concern of what each school's death education program consisted of and the length of time it was taught but the main concern of the study was what effect any sort of death education had on children's attitudes. Sample Size

The researcher had no control over the sample size. Each school that taught death education was asked to randomly select one class that had death education (Experimental group) and to match a similar grade level class that did not have death education (control group) to survey. There was no limit on class size so each 
school had a different number of students participating in the survey.

\section{TABLE 1}

SATPLE SIZE

\begin{tabular}{lcc}
\hline School & $\begin{array}{c}\text { N } \begin{array}{c}\text { of students } \\
\text { Control }\end{array} \\
\text { if of students } \\
\text { Exrerimental }\end{array}$ \\
\hline 2 & 8 & 8 \\
3 & 1 & 1 \\
4 & 17 & 17 \\
5 & 23 & 23 \\
6 & 18 & 18 \\
Total & 6 & 6 \\
\hline
\end{tabular}

\section{Procedure}

The major activities of this study were divided into three phases which were (1) planning and development or pre-active phase, (2) data collection or active phase, and (3) analysis or post active phase which included writing the report.

The following discussion gives a description of each activity. More detailed information can be found in the appropriate appendix and will be so designated. 
Pre-Active Phase

The planning period for this study began in August of 1977. Iruring this time the researcher became familiar with the topic of death education especially with the testing done by Hardt. bing a midale school educator, the researcher was interested in the effect of death education on midale/junior high school students.

Permission to Use Hardt's Instrument

In order to follow the same survey cone by Hardt, the researciner wrote to obtain his pormission to use his instrument the Death Attitude scale. On September 26, 1977 permission and an offer tor further help was received (Appendix C).

Determining the sample

In February of 1978 a package of inquiry was sent out to all of the superintendents of public, private and parochia.l miadle and junior high schools in ihode Island (115 in 211). This package contrined a letter to the superintondent which would acquaint him with the study (surveying attitudes of students who had been exposcd to a death education program) as well as ask his permission to send the sane inquiry package to the principals of his rniddle or junior high schools. Also available in the packet were copies of the instruments the researcher hoped to use in this study. These instrunents were a 
Principal's Survey, a Teacher's Survey, a Student Survey and the Hardt Death Attitude Scale (Aprendix BocC). After receiving his/her package, each superintendent then replied on a return postcard included in the inquiry package as to whether the researcier could contact the principals of his/her middle junior high schools (Appendix A). A follow up phone call was made to all superintendents who did not respond.

As permission was received the researcher sent out the same in uiry package to the principals of consenting schools. At this time the principal would answer a survey as to whether death education was taught in his/her school. Besides identifying the teachers of death education, the principals also indicated whether permission was granted to allow their students and teaches to participate in this study.

The results of this Principal's Survey was that six schools were identified in which six teachers taught death education in thode Island.

Active Yhase

Now that a test sample was identified, a paclage was sent to each teacher of death education in Rhode Island. The package contained a 'Teacher's Survey and approximately 60 copies of each of thie Student's survey and the Hardt Scalo to be given to students after death education was presented in class. 
The purpose of the Teacher's Survey was to obtain a description of what was being taught in the death education program as well as deternine the teacher's experience with presenting death education.

The Student's survey would obtain inforriation about student experiences with death while the Harat Scale would measure a student's attitude toward death.

\section{Post-Active Phase}

The third and final phase, the analysis of data phase, was carried out April 3, 1978 to April 17,1978.

After completing their death education programs teachers filled out the Teacher's Survey and adrinistered the post-test Student's Surveys and the Hardt Scale to students in one of their death education classes. Teachers also administered the Student's Surveys and the Hardt Scale to students in a class of the same grade level who did not have death education. Teachers who were willing also filled out a student survey and Hardt Scale theriselves in case implications could be drawn from teacher attitude influencing stident attitude towisd death.

\section{Description of Experimental Treatment}

Death education as presented in the six schools 
consisted of the discussion or presentation of the following topics: Suicide, Terminally Ill, Attitudes Toward Grief, Bereavement and Grief, Euthanasia, Funeral Services and Rituals, The Dying Process, Alternatives to Immediate Death, and Death as Identified in Masic, Literature and the Arts.

Activities included: viewing filmstrips, panel discussions, movies, writing, role playing and field trips.

While each school's program differed somewhat, it was still death education being taught and suitable for this study.

\section{Design of the study}

The experimental design is included to illustrate the independent and dependent variables in a design which controls for internal and external validity and determines the ast nt of generalizability of the findings of the study. This is followed by a discussion and illustration of the research design which serves the purpose of a framework within which the research questions can be answered. The statistical design of the study allows for interpretation of the comparisons made in the experimental design using statistical tests of significanee. 


\section{Experimental Design}

The type of experimental design used in determining the attitude toward death of students who had participated in death education as compared to attitude toward death of students who had not particinater in deatl education was a Fosttest Only Control Group Design. This design is based upon the experimental design as äefined by Gay $(1976,181)$. The design took this form: Figure 1.

$$
\begin{array}{lll}
R & X_{1} & 0 \\
R & X_{2} & 0
\end{array}
$$

$\mathrm{X}_{1}$ represents the treatment (death education) of one class of middle/junior high school students; $X_{2}$ represents the treatment (none) of the other class of middle/junior high school students; O represents the posttest given to each group.

Students in the classes tested were heterogeneously grouped thus causing the sample to be random. These groups were also the entire population f'rom schools in which jeath education was taugint. Each group was exposed to the independent variable, and posttested. Posttest scores for each group then were compared to detemine the effectiveness of the treatment.

The combination of randomization and the presence of a control group scrve to control for oll sources of intemal invalidity except mortality. Hortality is not 
controlled ror becave of the absence of pretest data on subjects. However, since the death erivcation programs were short ( 4 weeks at the Iongest) mortality did not prove to be much of a threat and pretesting did not seem practical because students might become test-wise after such a short duration.

The experimental design to deternine the efiects of death edrication on rnidale/jumior high school students in terms of a change in attitude toward death is diagrammed below.

\begin{tabular}{|c|c|c|c|}
\hline \multirow[b]{2}{*}{ Sample } & Treatme & & Posttest 0 \\
\hline & \multirow[t]{2}{*}{$x_{1}$} & \multirow{2}{*}{$\begin{array}{l}\text { death } \\
\text { ed. }\end{array}$} & \multirow{2}{*}{$\begin{array}{l}\text { posttest score } \\
\text { on attitude } \\
\text { toward death }\end{array}$} \\
\hline \multirow{2}{*}{$\begin{array}{l}2 \text { ranciomly } \\
\text { selected classes } \\
\text { from a school in } \\
\text { R.I. that teaches death } \\
\text { education }\end{array}$} & & & \\
\hline & \multirow{2}{*}{$x_{2}$} & \multirow{2}{*}{$\begin{array}{l}\text { no } \\
\text { death } \\
\text { ed. }\end{array}$} & \multirow{2}{*}{$\begin{array}{l}\text { postiest score } \\
\text { on attitude } \\
\text { toward death }\end{array}$} \\
\hline & & & \\
\hline
\end{tabular}

Figure 2. -- The Experimental Design

The independent variables of the study are those conditions which are raried or selected by the investigator. The independent variable in this study is: death education programs. The dependent variables are tire posttest scores on the Hardt Attitude Scale. 
Statistical Design

In order to determine the significance of the posttest score comparisons between the two groups, a directional "t" test for dependent samples was employed. The selected level of significance was .05. This level indicates that if the collection of data was duplicated an infinite number of times, similar results as found before would occur 5 times out of every hundred.

\section{Measurement}

Three instruments were used in this experiment: for the collection of data.

The Teacher's Survey was a descriptive instrument used only to determine a teacher's past experiences teaching about death and the content of his/her death education unit.

The Student's Survey was also a descriptive instrument used to detemine demographic data on a student as well as that student's experience with death in any form. The third instrument was the Death Attitude Scale developed by Hardt. This scale provides a measure for determining what an individual's attitude is toward death.

\section{Teacher's Survey}

A Teacher's Survey was used for two purposes. Pirst the researcher wanted to know what topics and activities 
were being included in the teacher's death education program. Second, it was important to discover the qualifications of the teacher in teaching the topic of death.

The teacher's survey consisted of a series of 13 open ended questions and 2 check list questions. Questions that investigated the content of the death education program were: 1. Check the topics that you include in your death education curriculum., 2. Where did you obtain your classroom materials on death?, 3. Name any filmstrips or speakers you have used in your program., ب.. What types or learning activities have your students participated in?.

The survey also sought to determine the teacher's professional background and qualifications bj asking such questions as: In what subject area(s) are you certiried?. How long have you been teaching?, Why do you teach about death?, What training have you had to present this topic?, and What has been the reaction of parents to your discussion of death?

\section{Student's Survey}

The Student's Survey, like the 'Teacher's Survey, sought to establish background information about each student. Information regajding a student's school, age, sex and grade was asked f'irst. Then, eleven questions followed to detormine how much experience a particular 
student had with death.

Questions included tile sollowing: * (1) What is your favorite TV program? The researcher hoped to discover whether a particular type of television show (violence vs. good family programs) had any effect on a child's attitude toward death. (2) Have you known someone who has been very sick? (3) Have you ever been very sick? (4) Have you ever had a pet that died? (6) Have you ever had a friend that died? (7) Has anybody in your house ever died? (8) Have you ever gone to a funeral?. These questions would determine how often a student had encountered near death or death situations within his/her own family circle. A student who has been exposed to many relatives dying may or may not have had his/her attitude toward death influenced.

Question (5) What are you most afraid of? hopes to determine if a child has a great fear of death. Questions $(8,9,10)$ Have you ever gone to a fineral? Do you go to church, a Synagogue, or Religious service? and What happens when you die? hope to discover what a student's religious experience is which may effect his/ her attitudes toward death.

Finally the question (1I) Have you ever read a story in which someone died? also seeks to discover to what extent literature plays in developing an individual's

* The number in parenthesis indicates the questions as numbered in the survey. 
attitude toward death.

The responses on the Teacher's Survey and the

Student's Survey are used to determine the exposure, in

a general sense, that these students have had with

experiences or information related to death.

Hardt's Death Attitude Scale

The Hardt scale is a Thurston EqualAppearing Interval Attitude scale designed to measure attitudes toward death. It consisted of 20 oddnumbered attitude statements ranging from 1.1 to $1.99^{\text {in } .2}$ intervals. Statements from 1.1 to 3.0 on the Death Attitude Scale are considered representative of death attitudes ranging from Very Unfavorable to Neither I'avorable nor Unfavorable respectively. Statements from 3.0 to 4.9 on the scale are considered representative of death attitudes ranging from Neither Favorable nor Unfavorable to Very Favorable respectively (Hardt, 1976, 269).

The scale has demonstrated validity, reliability, and readability by the fifth grade and up. Originally two scales. were developed by Hardt, scale A and B. Two types of validity were sought for each scale form. After employing four separate methods to meet concurrent and construct validity requirements, Form B demonstrated a higher degree of statistical validity than did Form A. Thus, Form B was chosen for use in this study.

"Two attempts were taken to determine the readability of the scale. Form B was readable by the fifth grade and up when judged by criteria set forth by Flesch (1949) 
and by Wale and Chall (1948)" (Hardt, 1975,97).

The Hardt scale was administered to two groups of students, a control group that had not been exposed to death education and an experimental group that had been exposed to death oducation. The Hardt Scale given in this study was changed slightly. Instead of numbering from 249-222 to facilitate scoring, the researcher numbered the questions from 1 to 20 so as not to confuse students. Since no wording had been changed the validity of the scale remained the same.

Students were asked to read each of the twenty items carefully and then to place a check mark next to the statements with which they agreed and to maire no marks next to the statements with which thoy did not agree. Before scoring could take place the researcher had to change his numbering of 1-20 back to Hardt's original system of 249-211.

The directions for scoring are as follows:

To score, simply disregard the first number (2), place a decimal point between the two remaining numbers, and average the respolnses. The average will fall either on an attitude statement or between two attitude statements. ixamle: an irdividual cliec is ilems $237(3.7), 235(3.5)$, and $227(2.7)$. By adding these together and dividing by the total number of iteris checked, an average of 3.3 is found. Hence, we can say that tinis person's attitude toward death at the time he/she took the test, is best described by statement $=33$, i.e., "I can accept tine thought of deatin" (Hardt, 1975,90). 


\section{Analysis of Data}

The STATPACK program for the IBM System/370 Hodel 155 at the University of Rhode Island was selected since this program was designed for the rost common statistical analyses. The program provided the moan scores for both the experimental and the control groups as well as providing additional data such as: the naximum, mininum, range, variance, standard deviation and standard error.

After the difference between the neans of the control group and the experimental group was detemined, a T-test was executed to determine whether the difference was statistically significant at the .05 level. 


\section{CHAPTLR IV}

FINDINGS AITD DISCUSSION OF RELULTS

A summary of the findings of this research and a discussion of the results are reported in this chapter. This chapter is divided into three sections. The first section deals with the findings related to the Teacher's Survey. The second section deals with the findings related to the Student's Survey. The third section deals with the findings related to the Hardt Attitude scale on which this entire study is based.

\section{Teacher's Survey}

Through the results of the Teacher's Survey the researcher hoped to discover the content of the death education programs in each of the six schools, and the background of a particular teacher regarding his/her qualifications or experiences in teaching about death.

Question 1: Please check the topics that you include in your death education curriculum, or topics that you have discussed with students in your particular discipline. 
TABLIL 2

DLATH EDUCATION CURRICULUM

Topics

Included
School

$\begin{array}{lllllll}1 & 2 & 3 & 4 & 5 & 6 & \text { Total }\end{array}$

$X \quad X \quad X$

$\bar{X}$

4

$\begin{array}{lllllll}X & X & X & X & X & X & 6\end{array}$

Terminally III

$\begin{array}{llllll}X & X & X & X & X & X\end{array}$

6

Attitudes toward

death

Bereavement and

Grief

Euthanasia

Funeral Services

and Rituals

$\mathrm{X} \quad \mathrm{X} \quad \mathrm{X} \quad \mathrm{X} \quad \mathrm{X} \quad \mathrm{X} \quad 6$

$\begin{array}{llll}X & X & X\end{array}$

$\begin{array}{lllllll}X & X & X & X & X & X & 6\end{array}$

The Dying

Process

$X \quad X \quad X$

3

Alternatives to

Imrediate Death

Death as icientified

in Music, Literature,

and the Arts
$\mathrm{X}$

1

The most popular topics discussed in all six schools were: terminally ill, attitudes toward death, bereavenent and gricf, and funeral services and rituals. The next most irequently discussed topics were: suicjde and euthanasia. These two topics were presented in five out of the six schools. The topic, tine dying process, was presented in three of the six schools and death as 
identified in music, literature and the arts was presented in only one of the six schools. The topic alternatives to immediate death was not discussed in any of the six schools.

Question 2: Flease list any additional topics that you include in your discussion of death.

Results:

School 1 - Sudden, accidental death Death of pets and enirals vs. family iespondine to frienas who have had some one close to them die

School 2 - Sick calls Anointing of the sick

School 3 - Stages of Death Stages of Grief Forced choices on death

School 4 - None

School 5 - Dealing with children What to do after funerals Social Security benefits Wills

School 6 - Cost Erfect on ramily Death of children

All six schools chose different additional topics based on student interest.

question 3: Where did you obtain your classroon materials on death?

Results:

School 1 - Youth groups, various sources School 2 - No answer

School 3 - Materials obtained at conferences 
School 4 - Home Ec. teacher, R.I.C. Curriculum Center

School 5 - State resources, Wilbert Inc. (pamphlets)

School 6 - Magezine articles, newspapers, books, personal observations

Five out of six schools obtained materials from

the various sources of: publications, other people and observation.

Question 4: Flease name any filmstrips, movies, or references that your children use during your discussion of death.

Results:

School 1 - Death - the I'inal itage of Growth by Lisabeth Kubler. Ross Film - Death of a Gaudi Dancer Filmstrip - Closing the Circle

School 2 - None

School 3 - Living With Dying

School 4 - Multi media kit - Perspectives on Dying - Discussing Death Self made tape - music that sings of death

School 5 - Filmstrip - A Taste of Blackberries

School 6 - lione

Four of the six schools presented filmstrips or movies on death, although none of the selections were similar. Question 5: Name any speakers you had to help present death and dying to jour students.

Results:

Sichool 1 - None

'school'2 - Priest 
School 3- None

School 4 - None

School 5 - None

School 6 - Minister, Priest, Nurse

Only two of the six schools had speakers during their death education unit. These speakers included a priest, a rilinister, and a nurse. The majority of schools (4) did not have any speakers on death.

Question 6: Please list any field trips that are part of your unit.

Results:

School 1 - None

School 2 - Funerals and wakes of relatives

School 3 - None

School 4 - INone

School 5 - None

School 6 - None

Only one of the six schools named a fieldtrip. However, the fieldtrip to the funeral or wake of a relative would not necessarily include an entire class, but only a few specific members in that class. The majority of schools held no fieldtrips.

Question 7: Check the type of learning activities in thich your students participate.

Results : 
TABLE' 3

DHATH EDUCAPIOA LUARING ACPIVITIUS

\begin{tabular}{|c|c|c|c|c|c|c|c|}
\hline \multirow{2}{*}{ Activity } & \multirow{2}{*}{ Totals } & \multicolumn{3}{|c|}{ school } & \multirow{2}{*}{4} & \multirow{2}{*}{5} & \multirow{2}{*}{6} \\
\hline & & 1 & 2 & 3 & & & \\
\hline Roleplaying & 3 & $x$ & & & & $x$ & $\mathrm{X}$ \\
\hline Brainstorming & 2 & . & & $\mathrm{X}$ & & & $\mathrm{X}$ \\
\hline Panel & 2 & & & & & $x$ & $\mathrm{X}$ \\
\hline Discussions & 6 & $x$ & $X$ & $X$ & $X$ & $\mathrm{X}$ & $\mathrm{X}$ \\
\hline Small Group Work & 2 & $X$ & & $X$ & & & \\
\hline View Filmstrips & 4 & $X$ & & $X$ & $\mathrm{X}$ & $x$ & \\
\hline View Films & 2 & $x$ & & & & $X$ & \\
\hline Audiotapes & 2 & & & & $x$ & $X$ & \\
\hline Writing & 4 & $\mathrm{X}$ & & $X$ & $X$ & & $\mathrm{X}$ \\
\hline Reading & 2 & $\mathrm{x}$ & & & & $\mathrm{X}$ & \\
\hline Give Reports & 2 & & & & & $x$ & $x$ \\
\hline Interviews & 2 & & & & & $x$ & $\mathrm{X}$ \\
\hline Ganes & 0 & & & & & & \\
\hline Others & 0 & & & & & & \\
\hline
\end{tabular}

All six schools included discussions in their study of death. The next most popular learning activities were viewing filmstrips and writing. Four of the six schools made use of these activities. Three schools used roleplaying. Two schools used the activities: brainstorming, panel, small group work, view lilms, audiotapes, reading, give reports and interviews. None of the six schools used 
games in the teaching of death or any additional topics not named on the survey form.

Question 8: In what areas are you certified?

Results :

School 1 - Social Studies

School 2 - Religion

School 3 - social Studies

School 4 - Social Studies, Science

School 5 - Religion

School 6 - Health

The most colmon area of certification for the six teachers of death education was social studies. Three of the six were certified in that area while two of the six were certified in religion and one of the six was certified in health.

Question 9: How long have you been teaching? Results:

$$
\text { TABLI } 4
$$

\section{THACIING WXIRIENCE}

\begin{tabular}{lc}
\hline School & Number of years teaching experionce \\
\hline 1 & 4 \\
2 & 32 \\
3 & 5 \\
4 & 2 \\
5 & 22 \\
6 & 10 \\
\hline
\end{tabular}


All six teachers have been teaching different lengths of time. The least number of years is two and the most is 32 years. The mean of teaching years of experience is twelve and one half years.

Question 10: Why did you start to teach about death? Results :

School 1 - To expand the student's knowledge of the life cycle

School 2 - Always has been part of school's religion program.

School 3 - "I came to learn that many people (including myself) fear death. I wanted to confront this fear and work through it"

School 4 - Students brought up topic many times on their own

School 5 - Part of school's religion program Student interest in subject

School 6 - Part of life everyone must pace

Four of the six teachers started teaching about death because they felt there was some sort of need. Two of the six teachers felt death education was a natural part of their religious education.

Question 11: How long have you been teaching about death?

Response: 


\begin{tabular}{ll}
1 & 2 \\
2 & always \\
3 & 3 \\
4 & 1 \\
5 & 1 \\
6 & 3 \\
\hline
\end{tabular}

Only one teacher had always been teaching about death. Two of the six had been teaching about death for three years. One of the six had been teaching about death for two years. Two of the six had been teaching about death for one year.

Question 12: What training have you had to present this topic?

Results:

School 1 - Attended workshop

School 2 - I am a priest

School 3 - Attended Conference

School 4 - Personal experiences

School 5 - Workshop

School 6 - Personal experiences

Three of the six teachers attended a workshop or conference on death education. One of the six teachers happened to be a priost. Two of the six teachers are 
basing their presentation of death on personal experience. Question 13: Dià you need parental pernission for a student to take part in your unit/discussion on death? Results:

School 1 - No

School 2 - iNo

School 3 - No

School 4 - No

School 5 - Yes

School 6 - INo

Five of the six teachers did not require permission of parents. One of the six teachers requirod a permission slip from the parents.

Question 14: What was the reaction of parents, if any, to your discussion of death?

Results:

School 1 - None

School 2. - Very upset in some instances

School 3 - None

School 4 - None

School 5 - None

School 6 - None

Only one teacher of the six surveyed had an angry parent. Five of the six teachers recorded no parental reaction to the teaching of death.

Question 15: Additional comments and/or sugsestions. 
Results :

School 1 - None

School 2 - Students became upset in some instances

School 3 - None

School 4 - None

School 5 - None

School 6 - None 


\section{Discussion}

These results suggest that there is no one curriculum for teaching the topic of death. A teacher creates a certain unit on death to suit the needs and interests of his individual class of students.

There is no one textbook on death education. Teachers in this study have cormiled thcir own resources and teaching materials. These materials were found everywhere; booss, articles, films, workshops, resource people and rersonal experiences.

The discussion method seemed to be the most valuable student activity for the teacher of death education. Discussion allows students to get their feelings out in the open where they can be examined. Students have shown a need to talk over the topic of death.

Writing is an activity that takes over when discussion stops. Sonetimes writing helps express a student's feelings when he or she is reluctant to speak.

For a school contemplating including death education into its curriculum cost should not be considered a major factor. All six of the experimental schools have demonstrated that resources are collected or borrowed, not necessarily bought. Costly items such as fieldtrips and equipment are not mandatory to the success of this subject area. Also, a school does not need to hire a specific teacher certified in death education. Ixisting 
teachers in the school can offer death education within the boundaries of their own subject areas. 'lhus, the cost of hiring additional personnel is unvarranted. An extensịve background is not necessary in teaching death education. All that is requirea is a teaching certificate in any area. and a person sensitive enough to recognize his/her feelings about death and those of his students. Readings and workshops will give plenty of infornation needed to teach the subject. Teachers of many subject area backgrounds could fit death education into their curriculum. Some include: social studies, religion, health, home economics, language arts and science. Finally the number of years experience in teaching does not seem to iniluence the success of a death education program. New and exierienced teachers alike, both have the opportunity and skill to present a meaningful unit in death education once they have identified this area of stuciy as pertinent to their studenis' needs. As the data indicated, these teachers inarle an eifort to become more infomed on death education before teaching tho subject. 
Student's Survey

Through the Student's Survey the researcher sought to discover some demographic information about each student as well as what experiences students have had related to death.

TABIE: 6

STUDENT DEMOGRAPHIC INFORIATION

\begin{tabular}{l|c|c|c|c|c|c|c|c|c|c|c|c|c|c}
\hline \multirow{2}{*}{ school } & No. & $M$ & $F$ & 10 & 11 & 12 & 13 & 14 & 15 & 5 & 6 & 7 & 8 & 9 \\
\hline 1 & 16 & 7 & 9 & 8 & 2 & 2 & 4 & & & 8 & 2 & 2 & 4 & \\
2 & 2 & 1 & 1 & & & & 2 & & & 2 & & & \\
3 & 34 & 14 & 20 & & & & 22 & 12 & & & & 34 \\
4 & 46 & 23 & 23 & & 2 & 22 & 22 & & & & 46 & & \\
5 & 36 & 36 & 0 & & & & & 16 & 20 & & & & 36 \\
6 & 12 & 7 & 5 & & & 7 & 5 & & & & 12 & & 36 \\
\hline 6 & 146 & 88 & 58 & 8 & 4 & 31 & 55 & 28 & 20 & 10 & 2 & 60 & 38 & 36 \\
\hline
\end{tabular}

The total survey was composed of 146 students, 88 male and 58 female. The students' ages were as follows: 8 -age 10, 4-age 11, 31-age 12,55 - age 13, 28 - age 14, and 20 - age 15. The students' grade levels were: 10 - grade 5, 2 - grade 6,60 - grade 7, 38 - grade 8, and 36 - grade 9.

The number of respondents was 146 from 6 schools. The majority of students who participated in this study. 
were male. The average age was 13 and the average grade was 7 th.

The following eleven questions were asked on this survey. All questions were voluntary and it was not mandatory for a student to answer every question.

Question 1: What is your favorite IV program?

Results: Due to the fact that so many different shows. were named only the top ten TV shows will be listed.

1. The Black Sheep Squadron

2. Three's Company

3. Saturday Night Live

4. Heppy Days

5. Chips

6. Hogan's Heroes

7. Love Boat

8. Baretta

9. lionty Python's Flying Circus

10. All in the Family

Question 2: Have you known someone who has been very sick?

Results: 
'PABLE' 7

STUDLNTS WHO KNEW SOMYONE VERY SICK

\begin{tabular}{cccc}
\hline & $\begin{array}{c}\text { Total responses } \\
\text { for each school }\end{array}$ & Yes & No \\
\hline 1 & 10 & 9 & 1 \\
2 & 2 & 1 & 1 \\
3 & 34 & 28 & 6 \\
4 & 46 & 39 & 7 \\
5 & 36 & 32 & 4 \\
6 & 11 & 11 & 0 \\
\hline 6 & 139 & 120 & 19 \\
\hline
\end{tabular}

Only 139 of the 146 students answered question 2. The majority of students (120) had known someone who has been very sick.

Question 3: Have you ever been very sick?

Results :

TABLE 8

STUDLNTS WHO HAD BEEN VHRY SICK

\begin{tabular}{cccc}
\hline & \multicolumn{1}{c}{ Total responses } & Yes & No \\
\hline Sor each school & 14 & 10 & 4 \\
2 & 2 & 0 & 2 \\
3 & 33 & 10 & 23
\end{tabular}


Table 8 cont.

\begin{tabular}{cccc}
\hline 4 & 45 & 19 & 26 \\
5 & 36 & 17 & 19 \\
6 & 11 & 5 & 6 \\
\hline $\begin{array}{c}\text { Total } \\
6\end{array}$ & 141 & 61 & 80 \\
\hline
\end{tabular}

Only 141 of the 146 students answered question 3. The majority of students $(80$ had not been very sick. Question 4: Have you ever had a pet that died? Results:

\section{TABLE 9}

SIUDLINS' WHO HAD PETS THAT DIHD

\begin{tabular}{cccc}
\hline & Total responses & & \\
\hline School & Yor each school & Yes & No \\
\hline 1 & 14 & 12 & 2 \\
3 & 2 & 2 & 0 \\
4 & 34 & 32 & 2 \\
5 & 46 & 37 & 9 \\
6 & 36 & 26 & 10 \\
\hline 6 & 12 & 11 & 1 \\
\hline
\end{tabular}

All but two of the 146 students answered this question. There was an overwhelming majority of students (120) that had a pet that died. 
Question 5: What are you most afraid of?

Results: Due to the fact that so many different items were named only the top ten items will be Iisted.

1. Death

2. Parent's Death

3. Iviy future

4. Nothing

5. Loneliness

6. Don't know

7. Spiders and snakes

8. Heights

9. Police

10. Storms

Question 6: Have you ever had a friend that died? Results:

TABLE 10

SIUDLENSS WHO HAD A FRIEND TIAT DIED

\begin{tabular}{cccc}
\hline & Total responses & Yes & No \\
\hline School & for each school & Yor & 8 \\
\hline 1 & 2 & 6 & 2 \\
3 & 34 & 14 & 20 \\
4 & 46 & 9 & 37 \\
5 & 36 & 17 & 19 \\
6 & 11 & 6 & 5 \\
\hline Total & 143 & 52 & 91 \\
\hline
\end{tabular}


One hundred forty-three of the 146 students responded to question 6. The majority of students did not ever have a friend die.

Question 7: ilas anybody in your house ever died? Results:

TABLE 11

STUDENTS WHO HAD SOMEONE IN THEIR HOUSL DIE

\begin{tabular}{cccc}
\hline & $\begin{array}{c}\text { Total responses } \\
\text { for each school }\end{array}$ & Yes & No \\
\hline 1 & 14 & 1 & 13 \\
2 & 2 & 0 & 2 \\
3 & 34 & 7 & 27 \\
4 & 46 & 8 & 38 \\
5 & 36 & 12 & 24 \\
6 & 11 & 3 & 8 \\
\hline Total & & 31 & 112 \\
6 & 143 & & \\
\hline
\end{tabular}

The majority of students had not had anybody in their house die. AII but 3 of the 146 students responded to question 7 .

Question 8: Have you ever gone to a funeral? Results: 


\section{TABLE 12}

STUDELITS WHO FAD ATIETDED A FUIVRAL

\begin{tabular}{cccc}
\hline School & $\begin{array}{r}\text { Total responses } \\
\text { for each school }\end{array}$ & Yes & iNo \\
\hline 1 & 14 & 9 & 5 \\
2 & 2 & 2 & 0 \\
3 & 34 & 14 & 20 \\
4 & 46 & 27 & 19 \\
5 & 36 & 36 & 0 \\
6 & 11 & 2 & 9 \\
\hline Total & 143 & 90 & 53 \\
\hline
\end{tabular}

The majority of students had attended a f'uneral. One hundred forty-three of the 146 students answered question 8.

$$
\begin{aligned}
& \text { Question 9: Do you go to Church, a Synagogue, } \\
& \text { or religious service (check) } \\
& - \text { regularly } \quad \text { often sometimes } \\
& - \text { seldom } \\
&
\end{aligned}
$$

Results: 
TABLE 13

ATTENDANCE AT CHURCH, SYNAGOGUA, OR AT

RELIGIOUS SERVICES

\begin{tabular}{|c|c|c|c|c|c|c|}
\hline School & $\begin{array}{l}\text { Total for } \\
\text { each school }\end{array}$ & Regularly & often & sometimes & Seldom & Never \\
\hline 1 & 14 & $I$ & & 2 & 3 & 8 \\
\hline 2 & 2 & 2 & & & & \\
\hline 3 & 34 & 6 & 8 & 12 & 4 & 4 \\
\hline 4 & 46 & 37 & 5 & $I$ & 2 & $I$ \\
\hline 5 & 36 & 11 & 5 & 10 & 7 & 3 \\
\hline 6 & 10 & 2 & & 3 & 4 & 1 \\
\hline \multicolumn{7}{|l|}{ TotaI } \\
\hline 6 & 142 & 59 & 18 & 28 & 20 & $1 \%$ \\
\hline
\end{tabular}

The majority of students attended a religious service at least sometimes, while only 37 of the 146 went seldom or never.

Question 10: What happens when you die?

Results: Due to the fact that somany different items were named only the top ten items will be listed.

1. You go to Heaven or Hell.

2. I don't know

3. Spirit goes to heaven

4. You are judged by God

5. You are judged by God

6. You get buried 
7. You rot

8. You collapse

9. You have an after life

10. Bugs eat you

Question 11: Have you ever read a story in which someone died? If yes, name it.

Results:

PABLE 14

STUDGITSS WHO HAD READ LIUERAIURE DEALING WIMI DEATH

\begin{tabular}{cccc}
\hline & & & \\
\hline School & $\begin{array}{c}\text { Total responses } \\
\text { for each school }\end{array}$ & Yes & iNo \\
\hline 1 & 10 & 6 & 4 \\
2 & 2 & 0 & 2 \\
3 & 34 & 27 & 7 \\
4 & 42 & 20 & 22 \\
5 & 32 & 29 & 3 \\
6 & 7 & 4 & 3 \\
\hline Total & 127 & 86 & 41 \\
\hline
\end{tabular}

The majority of students who respondod had read a story in which someone died. Below are listed the top ten books identified by the students.

1. The Day lo ligs Would Die

2. The Rise and Fall of Adolph ilitler

3. Of Wice and Hen 
4. Lord of the Flies

5. My Enomy, My Brother

6. Death Be Not Proud

7. Love Story

8. Cheaper by the Dozen

9. Brian's Song

10. Death of a Salesman 
Discussion

The results indicate that the majority of students surveyed have had experiences with death. However, most of the experiences have not been on a personal level. Most of the students' experiences were knowing someone who was sick or reading about death. While a majority of students had had a pet die, only 31 had somebody in their house die.

Having death removed from one's personal experiences suggeststhe need to prepare one for the day death will occur in his/her own family circle. Talking about a friend's death, attending the funeral of a friend, or reading about death will encourage the acceptance of death and prepare a student for more personal confrontations with death.

The most feared item on the survey was death. Students fear their death and the death of their parents because it is a mystery to them. It is something that is unknown. Talking about one's own death or the death of a family member will not answer all the mysteries but it can reduce fear of death.

The majority of students surveyed attend a religious service of some sort at least sometimes so the idea of death should be a common one even if it is not discussed often. Religion could be a way of confronting the mystery of death by some students. 
$59:$

Finally the list of television programs and books identifies some of the resources Irom. Which these students gain knowledge about death. 
The Hardt Death Attitude Scale

Results from the Hardt Death Attitude Scale

determined whether death education improved the attitudes toward death in rniddle school/junior high school students.

Two groups of students were randomly selected by class and matched by grade level in each of the six schools. The control group was given the Hardt scale to complete after receiving no treatrent. The experimental group was given the Hardt scale to complete after being exposed to a unit on death education. The score of each student for the six schools is recoried in a chart in Arpendix D.

The mean score for the total control group of all six schools was 2.859. The mean score for the total experimental group of all six schools was 3.148. The difference between the two means was .289. To determine whether .289 was a significant difference between the mean scores of the two groups a T-test for dependent samples was employed (dependent meaning matched).

Results:

TABLE 15

T-TEST

\begin{tabular}{llccc}
\hline $\begin{array}{l}\text { Control } \\
\text { Mean }\end{array}$ & $\begin{array}{l}\text { Experimental } \\
\text { Mean }\end{array}$ & $\begin{array}{l}\text { Degrees Level } \\
\text { Freedom Signif. }\end{array}$ & $\begin{array}{c}\text { Computed } \\
\text { T value }\end{array}$ \\
\hline 2.859 & 3.148 & 72 & .05 & 3.31050 \\
\hline
\end{tabular}


For $p=.05$ and $d f=72$, the table value for $t$ required for rejection of the null hypothesis is 2.000. Since our value is 3.31050 and sreater than 2.000 there is evidence that a "gain" in death attitude scores has talren place between the two groups. Hence, statistically, there has been an improvement toward a more postitive attitude as measured by the Hardt Death Attitude Scale. Therefore, the null hypothesis is rejected. (There is no significant difference in attitudes toward death between students who have been exposed to death education in school and students who have not been exposed to death education.)

Additional tests were given to detemine whether a . gain in de:th attitude score had taken place in each of the six schools.

Results:

TABLE 16

MEAN VALULS FOR INDIVIDUAL SCHOOLS

\begin{tabular}{llll}
\hline school & Mean-Experimental & Mean-Control & Difference \\
\hline 1 & 2.618 & 2.198 & .420 \\
2 & 2.922 & 2.120 & .802 \\
3 & 3.211 & 3.135 & .076 \\
4 & 3.102 & 3.047 & .055 \\
5 & 3.341 & 2.736 & .605 \\
6 & 3.306 & 2.722 & .584 \\
\hline
\end{tabular}


TABLE 17

T-TESTS FOR INDIVIDUAL SCHOOLS

School T Value Degrees of $\begin{aligned} & \text { Teforet. Significant? } \\ & \text { of nulj. } \\ & \text { Hypothesis }\end{aligned}$

\begin{tabular}{lccll}
1 & 1.61459 & 7 & 2.365 & No \\
2 & CAN'T & COMPUTE & & \\
3 & 0.44287 & 16 & 2.120 & No \\
4 & 0.43402 & 22 & 2.074 & No \\
5 & 2.89122 & 17 & 2.110 & Yes \\
6 & 2.14463 & 5 & 2.571 & No \\
\hline
\end{tabular}

Only in school \#5 was the T-value greater than the T required for the rejection of the Null Hypothesis. Therefore only in school $\# 5$ had an improvement toward a more positive attitude toward death taken place.

From the above data it seems to indicate that school \#5, the parochial school, has the most effective death education program. However school \#5 is also an all male school with the oldest group of students surveyed. In looking at question one: Is there a difference between the death attitude of students attending private and parochial schools and the students attending public schools after they have been exposed to death education? the researcher cannot be sure that the factor, being a parochial school, influenced the positive change. The other two factors, 
all male and older students, might also have been responsible for the change.

The second question examined was: Does the type of death education program have an effect on students' attitudes toward death in the participating survey schools? Based upon the results of the Teacher's Survey it was found that each teacher surveyed created his/her own death education unit based on the needs of individual students. Each school presented different topics on death using varied methods. There was no set type of death education program. This information seerns to indicate that the content of curriculum and the method of teaching were not factors in changing a students' attitudes toward death. 


\section{Discussion}

Results from the Hardt Death Attitude Scale indicate that death education is beneficial at the middle/junior high school in changing a student's attitude to be more positive toward death.

The composition of the death education unit does not seem to be a factor in this change of attitude, nor does teacher qualifications.

In comparison to Hardt's study in which he had a predominately female population (76\% female, $24 \%$ male), this sample included $60 \%$ male and $40 \%$ female. Whereas in determining a change of attitude within schools, school \#5 which had a significant change in attitude was an all male school. This data indicates that sex has no influence on changing an attitude toward death. 


\section{SUMMARY AND IMPLICATIONS}

\section{Summary}

The purpose of this study was to determine whether death education programs had any significant effect on the change in attitudes toward death of middle/junior high school students.

The research took place in the six schools in Rhode Island where death education was taught.

A posttest only control group design was used in the study with 146 students randomly assigned to two matched groups. The control group received no treatment and the experimental group received a death education program.

Three instruments were used - (1) Teacher's Survey to determine the content of death education programs, (2) Student's Survey to determine students' background of death related experiences, (3) Hardt Death Attitude Scale to measure a student's attitude toward death.

\section{Major Findings}

It was determined that there was a statistically significant difference between the test scores of students who had not been exposed to death education and the test scores of students who had been exposed to death education. This difference indicated that death education was in fact effective in changing the attitude toward death of middle/ junior high school students.

Since there was no set type of curriculum for each 
school it seems that the content of curriculum and the method of teaching were not factors in changing a student's attitude toward death.

Due to the nature of this survey and such a small sample it was impossible fol the researcher to determine whether a parochial school actually makes a significant difference in changing a student's attitude toward death. Implications

This study indicates that a death education program may be the answer for dealing with youth's cry ror honest information regarding death.

Since only a small number of schools in Rhode Island include death in their curriculum there is reason to believe that the majority of school systems are afraid to offer a perhaps somewhat controversial subject. It is the researcher's attempt, through this study, to encourage the school systems in Rhode Island to take à second look at what death education can offer their students - a happier and more purposeful Iife!

If this attempt is to be worthwhile more research in the field of death education must continue both in Rhode Island and the nation.

Additional topics for study could include: (I) What teaching methods are most effective in a death education program? (2) Does teacher personality and performance effect a student's attitude toward death? (3) What are the parental reactions to existing death education programs? and (4) Do religious background and the parental response system affect a student's attitude toward death? 
APPENDIX A

PRE-ACTIVE PHASE 
Mary C. Canole

6 Calvert Street

Newport, Rhode Island 02840

March 7, 1978

Dear Superintendent:

As a teacher for the past three years, I have become increasingly aware of student's lack of information concerning death and dying. Death education is a valuable part of any child's growth. Children naturally seek information about death and they need to be able to express their thoughts and concerns about death openly. In completing my master's degree at the University of Rhode Island my thesis is. entitled "A Measurement of the Improvement of Attitudes. Toward Death in Middle/Junior High School students". I would like your permission to have some of the teachers in your s.chool district participate (on a voluntary basis) in my survey.

Enclosed is a packet of materials for your examination, I hope that your community can contribute to this study. Return the enclosed postcard indicating your decision.

Although you may not have any formal unit on death and dying presented in your schools, I am sure that some of your teachers have been urged by their students to deal with this relevant topic. My goal is to contact these teachers whether they be English teachers - discussing death in a writing of literature course, Home Economics teachers - presenting death as part of the family life cycle; or Social studies teachers - suggesting the importance of life insurance. With this help I hope to discover to what extent death education is included in the curriculum and how diversified is the approach. As a teacher of Home Economics I feel that this topic is essenial to the mental health of all young people. It is often overlooked in the curriculum, yet it emotionally touches the lives of all our students.

Thank you for your time in reviewing the enclosed material. I ask you to accept the challenge of discovering what has been done in your schools about teaching any aspects of this topic.

Sincerely,

"laiyc Canole
Mary c. Canole
Master's Candidate

: University of Rhode Island

Advisor

Patricia S. Kally, Ph.D

Chairman, Home Economics Dept.

University of Rhode Island 


\section{RETURN POST CARD}

Please check one of the following:

___ You have my permission to contact Principal ${ }^{\text {at }}$ in of school $\mathrm{my}$ community My community will be unable to participate in jour survey.

Comments or Suggestions: 
Mary C. Canole

6 Calvert street

Newport, Rhode Island 02840

March, 1978

Dear Middle/Junior High School Administrator:

I am a graduate student at the University of Rhode Island and I am presently working on my Master's Thesis: "A Measurement of the Impro vement of Attitudes Toward Death in Middle/ Junior High School students". I am writing to you to determine whether or not your middle school/funior high school offers any program or classes in Home Economics, Health, Social Studies or any subject area that deals with the subject of Death Education.

If so, I would like to survey the teachers and the students in order to find out whether death education reduces a child's anxiety toward death. I would also like to survey a group of students in your school who have not been exposed to death education. Enclosed is a copy of the survey your teachers will receive.

In reporting my findings, complete confidentiality in regard to your school and names of your teachers and students is assured. I also will be glad to share my findings with you.

Please return the enclosed questionnaire by March 23, 1978 so I may begin implementation of this study.

Thank you for your cooperation. I look forward to hearing from you.

Sincerely,

Mary Cinale

Mary C. Canole

Master's Candidate

University of Rhode Island

Advisor

Patricia S. Kelly, Ph.D

Chairman, Home Economics Dept.

University of Rhode Island 


\section{PRINCIPAL'S QUESTIONNAIRE}

Please answer completely and return in the enclosed stampaddressed envelope no later than March 23, 1978.

1. Name of School

2. Address

3. Phone Number

4. Name of Principal

5. (Please check the following statements if it applies to Jour Middle/Junior High School.)

No, we do not offer any death education program in our school

Yes, we do offer some Death Education in the

\section{Subject} program at our school.

Yes, we would be willing to survey students that have been exposed to death education. No, we would not be willing to post-test students that have been exposed to death education.

6. List below the names of your teachers who include a Unit or teach concepts on death education in his/her program. Names of teachers Subject Matter Area

7. We do not have death education in our school presently because:

no one is qualified to teach such a course or unit of instruction it is too controversial a topic

parents would disapprove children would become upset other (please explain) 
it is taught in the High School

8. Additional comments and/or suggestions. 
APPENDIX B

ACTIVE PHASE 
1. Please check the topics that you include in your death education curriculum, or topics that you have discusses with students in your particular discipline.

Suicide

Terminally ill

Attitudes toward

death

Bereavement and

Grief

Death as identified in music, literature and
Buthanasia

Funeral Services and Rituals The Dying Process

Alternatives to Immediate Death

the arts

2. Please list any additional topics that you include in your discussion of death.

$$
\begin{aligned}
& 1 . \\
& 3 .
\end{aligned}
$$

3. Where did you obtain your classroom materials on death?

4. Please name any filmstrips, movies, or references what your children use during your discussion of death.

5. Name any speakers you have to help present death and dying to your students.

$$
\begin{aligned}
& 1 . \\
& 3 .
\end{aligned}
$$

6. Please list any field trips that are part of your unit. 3.

7. Check the types of learning activities in which your students participate.

$\begin{array}{lll}\text { 1. Role Playing } & \text { 6. View filmstrip } & \text { 1l. Give } \\ \text { 2. Brainstorming } & \text { 7. View films } & \text { Reports } \\ \text { 3. Panel } & \text { 8. Audiotapes } & \text { 12. Inter- } \\ \text { 4. Discussions } & \text { 9. Writing } & \text { views } \\ \text { 5. Small Group Work } & \text { 10. Reading } & \text { 13. Games } \\ & & \end{array}$

8. In what subject area(s) are you certified? 
9. How long have you been teaching?

10. Why did you start to teach about death?

11. How long have you been teaching about death?

12. What training have you had to present this topic?

13. Did you need parental permission for a student to take part in your unit/discussion on death?

14. What was the reaction of parents, if any, to your discussion of death?

15. Additional comments and/or suggestions. 


\section{Student Survey}

\section{DEATH EDUCATION}

Fill in the Blanks:

School

Sex

my age

Grade

My Family Members (Iist)

First Name

I.

Age

2.
3.
5.
6.

Briefly answer the following questions.

1. What is your favorite T. V. program?

2. Have jou known someone who has been very sick?

3. Have jou ever been very sick?

4. Have you ever had a pet that died?

5. What are you most afraid of?

6. Have you ever had a friend that died?

7. Has anybody in your house ever died?

8. Have you ever gone to a funeral?

9. Do you go to Church, a Synagogue, or Religious Servicas (check)

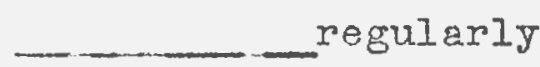

often sometimes

seldom

nevor

10. What happens when you die?

11. Have you ever read a story in which someone died? If Jes, name it.

Turn to the next page and read the directions carefully. 
APPENDIX C

HARDT INSTRUMFNT 
78

Date $-9 / 27$

I, Dr. Vale V. Hard, give Mary C. Canola permission to use in total my instrument that measures attitudes toward death as published in the February 1975 issue of the Journal of School Health for her vaster's Thesis study.

I also give her permission to change some of the more sophisticated vocabulary to suit the middle school aged child.

Lr. Dale V. Hard

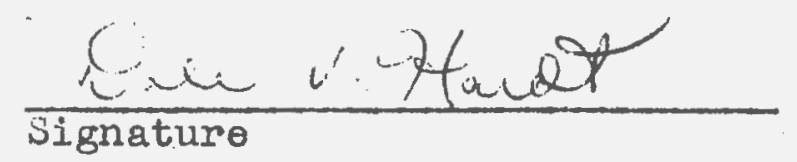


Directions: Read each item carefully. Place a chock mark next to each item with which you AGREE. Make NO MARKS next to the items with which you disagree.

1. _. The thought of death is a glorious thought.

2. When I think of death I am most satisfied.

3. Thoughts of death are wonderful thoughts.

4. The thought of death is very pleasant.

5. The thought of death is comforting.

6. I I I Ind it fairly easy to think of death.

7. ___ The thought of death isn't so bad.

8. _.... I do not mind thinking of death.

9. I can accopt the thought of death.

10. To think of death is common.

11. I _ I don't fear thoughts of death, but I don't like them either

12. _..... Thinking about death is over-valued by many.

13. _. Thinking about death is not fundamental to me.

14. _. I find it difficult to think of death.

15. _... I regret the thought of death.

16. _.. The thought of death is an awful thought.

17. _ The thought of death is dreadful.

18. The thought of death is traumatic.

19. __. I hate the sound of the word deatin.

20 . The thought of death is outrageous.

(This test taken from Dale V. Hardt, Journal of School Health, XIV \#2, February 1975, P96-99.) 
A BIIEF SUMHARY OF VALIDITY COEFFICIENTS FOR THE HARDT SCALE

\begin{tabular}{|c|c|c|c|c|c|}
\hline $\begin{array}{l}\text { Type of } \\
\text { Validity }\end{array}$ & $\begin{array}{c}\text { Statistical } \\
\text { Test }\end{array}$ & $\begin{array}{l}\text { Scale } \\
\text { Form }\end{array}$ & $\begin{array}{l}\text { Level of } \\
\text { Acceptance }\end{array}$ & Findings & $\begin{array}{l}\text { Accep- } \\
\text { tance? }\end{array}$ \\
\hline Concurrent & Correlation & $\begin{array}{l}A \\
B\end{array}$ & $\begin{array}{l}.75 \\
.75\end{array}$ & $\begin{array}{l}.75 \\
.84\end{array}$ & $\begin{array}{l}\text { Yes } \\
\text { Yes }\end{array}$ \\
\hline $\begin{array}{l}\text { Construct } \\
\text { (Type I) }\end{array}$ & Correlation & $\begin{array}{l}A \\
B\end{array}$ & $\begin{array}{l}.75 \\
.75\end{array}$ & .94 & $\begin{array}{l}\text { Yes } \\
\text { Yes }\end{array}$ \\
\hline \multirow[t]{2}{*}{$\begin{array}{l}\text { Construct } \\
\text { (Type II) }\end{array}$} & $\begin{array}{l}\text { Directional } \\
\text { "t" Test } \\
\text { (Means) }\end{array}$ & $\begin{array}{l}A \\
B\end{array}$ & $\begin{array}{l}.05 \\
.05\end{array}$ & $\begin{array}{l}t 14=1.192 \\
t 14=1.78\end{array}$ & $\begin{array}{l}\text { No } \\
\text { Yes }\end{array}$ \\
\hline & $\begin{array}{l}\text { Directional } \\
\text { "t" Test } \\
\text { (Variances) }\end{array}$ & $\begin{array}{l}A \\
B\end{array}$ & $\begin{array}{l}.05 \\
.05\end{array}$ & $\begin{array}{l}\operatorname{t1} 3=1.43 \\
\operatorname{t1} 3=11.664\end{array}$ & $\begin{aligned} & \text { No } \\
4 & \text { Yes }\end{aligned}$ \\
\hline
\end{tabular}

"Using the split half method of reliability with the Spearman-Brown "Prophecy Formula" serving as an adjustment formula, a reliability coefficient of .87 was produced for Form B. Form A produced a reliability coefficient which was not acceptable as a demonstration of reliability (fiardt, 1975,97)." 
APPENDIX D 
HARDT SCALL SCORLS

School

Control

Experimental

1

1.850

2.900

2.660

1.922

1.850

2.200

1.700

2.500

3.333

3.220

2.055

2.950

2. 300

1.371

2.786

2.433

2

2.120

$2.92 c^{\prime}$

3

2.957

3.233

3.233

2.780

2.050

3.200

3.700

3.266

3.100

3.400

3.300

3.460

3.300

3.200

4.077

2.500

3.400

3.500

3.600

3.380

2. 300

3.420

ㄴ..071

2.900

2.950

3.625

3.477

3.500

3.266

2.600

c. 060

3.420

2. 144

2.833

4

3.360
2.350

3.233

3.271

2.203

3.788

3.380

3.460

3.4 .00

3. 271

3. 271

2.933

3.220

3.200

3.100

2. 350

2.528 


\begin{tabular}{|c|c|c|}
\hline & $\begin{array}{l}3.500 \\
3.202 \\
2.900 \\
2.900 \\
2.900 \\
3.266 \\
3.460 \\
2.966 \\
2.380 \\
3.100\end{array}$ & $\begin{array}{l}2.766 \\
3.475 \\
3.300 \\
3.460 \\
3.1 .00 \\
2.900 \\
2.800 \\
2.240 \\
3.475 \\
2.250\end{array}$ \\
\hline 5 & $\begin{array}{l}1.922 \\
3.000 \\
2.200 \\
3.266 \\
2.500 \\
1.958 \\
3.100 \\
3.333 \\
2.900 \\
3.757 \\
2.800 \\
2.050 \\
3.900 \\
2.100 \\
3.300 \\
1.050 \\
3.614 \\
1.700\end{array}$ & $\begin{array}{l}3.962 \\
3.233 \\
3.380 \\
3.600 \\
2.900 \\
3.733 \\
3.100 \\
3.586 \\
3.100 \\
3.400 \\
3.350 \\
3.877 \\
3.400 \\
3.300 \\
3.200 \\
2.740 \\
2.660 \\
3.620\end{array}$ \\
\hline 6 & $\begin{array}{l}2.850 \\
2.900 \\
1.922 \\
2.900 \\
3.100 \\
2.660\end{array}$ & $\begin{array}{l}3.460 \\
3.100 \\
3.1+50 \\
3.271 \\
2.766 \\
3.708\end{array}$ \\
\hline
\end{tabular}


BIBLIOGRAF HY 


\section{REFERENCES}

Ames, Louise Bates. "Death: Ways to Help Children Get Perspective". Instructor, LXXVII No. 5. (January 1969), 59-118.

Anthony, S. The Child's Discovery of Death. New York: Harcourt Brace, 1940.

Aries, Philippe. Western Attitudes Toward Death: From The Middle Ages to the Present. Baltimore, Maryland: The John Hopkins University Press, 1974.

Arnstein, Flora J. "I Met Death One Clumsy Day". English Journal, LXI No. 6 (September 1972), 853-858.

Berg, David W.: and Daugherty, George-G.. "Teaching About Death". Today's Education, LXII No. 3 (March 1973). $46-47$.

Brown, Mackey. "Talking to Children About Death". Family Circle, March 27, 1978, 80,156,160,162,164.

Childers, Perry, and Wimmer, Mary. "The concept of Death in Early Childhood". Child Development. XIII No. 4 October 1971). 1293-1301.

Choron, Jacques. Death and Modern Man. New York: Collier Books, 1972.

Choron, Jacques. Death and Western Thought. New York: Collier Books, 1973.

Cox, Gerry R., "An Analysis of Factors Influencing Attitudes Toward Death" (Richmond, Indiana: Eric Document Reproduction Service, ED 138 862, 1976).

Dale and Chall. "A Formula for Predicting Readibility". Education Research Bulletin, XXVII (1948), 194.

"Death Education: A Living Issue". Science Teacher, XLIII No. 7 (October 1976), 21-23.

"Death Fducation and Death Fear Reduction". Education. XCVII No. 2 (Winter 1976), 145-148.

Dickinson, George E.. "Death Education in Medical Schools in the united States" (St. Louis, Missouri: Eric Document Reproduction Services, ED 130 861, 1976). 
Dulak, Joseph A., "Relationship Between Individual Attitudes Toward Life and Death". Journal of Consulting and Clinical Psychology, XXXVII No. 3 (June 1972), 463.

Elking, David. "Life and Death: Concepts and Feelings in Children", Day Care and Early Childhood, IV No. 3 (January - February 1977), 27-29, 39.

Feifel, Herman, ed. The Meaning of Death. New York: McGraw-Hill : Book Co., 1965.

Flesch. The Art of Readable Writing. New York: Harper and Brothers, 1949.

Fontenot, Christine. "The Subject Nobody Teaches". English Journal. LXIII No. 2 (February 1974), $62-63$.

Formanek, Ruth. "When Children Ask About Death". Elementary School Journal, LXXV No. 2. (November 1974), 92-97.

Fulton, Robert L., "Death and Dying: Some Sociological Aspects of Terminal Care", Modern Medicine, 40 (May 29, 1972), 74-7.

Gay, L. R., Educational Research. Competencies For Analysis and Application. Ohio: Charles E. Merrill Publishing Co., 1976.

Green, Betty R., and Irish, Donald P., Death Education Cambridge, Mass.: Schenkman Publishing Co., 1971.

Grollman, Earl A. ed.. Concerning Death: A Practical Guide for the Living.

Hardt, Dale V... "A Measurement of the Improvement of Attitudes Toward Death". Journal of School Health, XLVI No. 5 (May 1976), 269-270.

Hardt; Dale V.. "Development of An Investigatory Instrument to measure Attitudes Toward Death". Journal of School Health, XLV No. 2 (February 1975), 96-99.

"Helping Children Understand Death". Young Children: XXXII No. 1 (November 1976), 20-25. 
Hillway, Tyrus. Handbook of Educational Research. Massachusetts: Houghton Mifflin Company, 1969.

Hollis, James, "The Relevance of Death", The Chronicle of Higher Education, $X$ (May 27, 1975)., 24.

Irish, Jerry A.. A Boy Thirteen. Philadelphia, Pennsylvania: Westminister Press, 1975.

Kavanaugh, Robert E.. Facing Death. California: Nash Publishing Co., 1974.

Kubler - Ross, Elisabeth. Death - The Final State. of Growth. New Jersey: Prentice-Hall, Inc., 1975.

Kubler - Ross, Elisabeth. On Death and Dying. New York: Macmillan Publishing Co., 1969.

Kubler - Ross, Elisabeth. Questions and Answers on Death and Dying, New York: Macmillan Publishing Co., 1974.

Kubler - Ross, Elisabeth. "The Searching Mind". Today's Education, LXI (1972), 32.

Langone, John. Death Is a Noun. Boston, Massachusetts: Little, Brown and Company, 19.72.

Leviton, Daniel"Education for Death". Journal of Health, Physical Education and Recreation, X工 No. 7 (September 1969), 46-47.

"Looking At: Death and Dying". Eric Report, (November 1975), 14-17.

"Love, Death and Liberal Education". Liberal Education. LXII No. 3 (october 1976), 444-456.

Mack, Arien, ed.. Deáth in American Experience, New York: Schocken Books, 1973.

Mills, Gretchen C.: Reisler, Raymond, Jr.; Robinson, Alice E.; and Vermilye, Gretchen. Discussing Death. ETC Publication, 1.976.

Mitchell, Marjorie Editha. The Child's Attitude To Death. New York: Schocken Books, 1967.

Nelson, Richard C., and Peterson, William D.. "Challenging the Last Great Taboo: Death". School Counselor, XXII No. 5 (May 1975), 353-358. 
"On Teaching Death and Dyine". Media and Methods, XIII No. 6 (February 1977), 56-59.

Otero, George G.. Death: A Part of Life. An Experimental Unit. Colorado: Center for TeachingInternational Relations, 1975.

Schmitt, Abraham. Dialogue With Death, Texas: World Books, 1976 .

Schneidman, Edwin S.. "You and Death". Psychology Today, V (June 1971), 44 .

Shibles, Warren. Death - An Interdisciplinary Analysis. Wisconsin: The Language Press, 1974.

Skinner, Denise A.. "Death Education - Preparation for Living", What's New in Home Economics, XI No. 7

(April 5,1976$), 3-6$

Stanford, Gene, and Perry, Deborah. Death Out of the Closet, New York: Bantam Books, 1976.

Swenson, Evelyn J.. "The Treatment of Death in Children's Literature". Elementary English, XLIX No. 5 (March 1973), 401-404.

"Symbolic Immortality - A New Approach to the Study of Death", Media and Methods, XIII No. 6 (February 1977). 60-64.

Turabian, Kate L.. A Manual for Writers. Chicago: The University of Chícago Press, 1973.

Wise, Doreen, "Learning About Dying". Outlook, XXII No. I (January 1974), $42-44$.

Zazzero, Joanne. "Death Be Not Distorted". Nation's Schools, XCI No. 5 (May 1973), 39-42. 